\title{
Deliberative Efforts Toward a Green Economy: A Case Study of Canada
}

\section{Kiara Yllescas}

By deconstructing Canada's current system of environmental management, improvements to current policies can be made in order to reach goals which not only meet but exceed environmental expectations provided by the United Nations Framework Convention on Climate Change (UNFCCC). Canada's Changing Climate Report (CCCR) 2019 has shown the highest rates of warming ranging from $1.7^{\circ} \mathrm{C}$ to $2.3^{\circ} \mathrm{C}$ since their initial report in 1948 . This report from 2019 indicates that Canada is experiencing global warming at twice the rate of the $0.8^{\circ} \mathrm{C}$ global average (Bush and Lemmen). Canada's nationwide audits have stated goals to cut emissions, but no detailed plans, timelines, funding or expected results have been provided. No level of government in Canada is prepared to apply these actions nor adapt to the impacts of climate change. With several targets and no initiative to reach them, it is clear that Canada's system of environmental management needs improvement. Reconstruction of communicative practices and reformation of current policies can ensure sustainability across all sectors. Through communicative changes and policy reforms, effective changes to both the economy and ecology can be reached. Deliberative polling in a networked environment lays the foundation toward representing non-human actors (non-human nature and future generations), full transparency, and sustainable goals.

Keywords: green bonds, deliberative polling, sustainable goals, UNFCCC, environmental management

\section{| Bridging Traditional and Non-traditional Methods of Communication}

In order to meet the UN's goals and shift to a green economy, effective processes of communication and political reform must be employed. Canada can effectively manage these new endeavours by constructing new forms of involvement for public and private sectors to ensure engagement. Through non-traditional methods of involvement, they can ensure engagement for all in order to change patterns of political participation as it is now. In order to achieve transparency with citizens, issues regarding economic activities, transition toward renewable energy sources, and managing projects should be discussed deliberately in order to meet the Paris Agreement. Canada's commitment to reduce its greenhouse gas emissions by 30\% below its 2005 levels is highly ambitious. In order to reduce greenhouse gas emissions to the level to which they have committed, it must reach every corner of the economy. To reach every corner is to transform sectors: energy supply, industry, digital, 
building, transport, food consumption, and further nature based solutions. "Achieving a $1.5^{\circ} \mathrm{C}$ planet will require the fastest economic transition in history. This transformation is both necessary and achievable" (Falk \& Gaffney, 2020).

In Foundations and Frontiers of Deliberative Governance, John Dryzek describes his four pillars of deliberative democracy which we can use to analyze the ways in which Canada's environmental management lacks the necessary framework needed to reach its targets. The four pillars are (1) Legitimacy, (2) Representation, (3) Communication and Rhetoric, and (4) Pluralism and Meta-consensus. Within citizen forums, simple fiscal sampling guarantees representativeness as it is ensured that participants can represent the population equally. This approach can also be applied to the global level, where participants must be systematically chosen. The legitimacy of the collective decision lies in the results of the subject and the consequential deliberation. By applying new forms of political communication facilitated by the federal government, meaningful discourse can be coordinated in order to discuss key challenges which Canada faces. Because the environment is a non-human actor, its disturbances must be communicated through some sort of deliberation in order to reflect on the needed reforms (Bryer 509). Cooperative reformation which considers both capital and sustainability is possible, but requires collaborative efforts on behalf of the government, businesses, and citizens (Hajer 200). By acknowledging everyone's responsibility to reduce fossil fuels, Canada can start divesting from them while investing in energysaving technologies. This is also crucial to compliance with the UNFCCC. Through the deliberative process these policies can be restated, complied with, and protected.

Raeijmaekers and Maeseele recommend an approach that focuses on critical pluralism:

To allow a broad democratic debate on neoliberal principles, there is an urgent need for the contestation of these principles in multiple arenas. From our analysis, only the critical pluralismapproach comes forward as able to evaluate public discourse, and media discourses in specific, on the extent to which a democratic debate on these principles is encouraged, with a legitimate expression of dissensus and different alternatives. (Raeijmaekers \& Maeseele)

This approach complies with essential measures that protect and place responsibility on environmental concerns. What deliberation offers is public meetings in which participants collaborate and come to a collective decision for the public good and well-being of human and non-human actors. Through this process, transparency of the nation-state's budget should be provided in order to meet the ecological and capital goals, with the intention of providing transparency in order to sustain a non-human actor's goals with this system.

Heike Graf provides a speculative observation of both human and non-human actors. The non-human environment influences communication. Non-human actors also include the environment and the unborn humans. The future of non-human actors is under a large threat which has not properly been communicated to the public. The Environment in the Age of the Internet: Activists, Communication, and the Digital Landscape seeks to explain that without communicating our environment (non-human), then no knowledge of dangers such as climate change, pollution, and deforestation can be made a social concern. The non-human environment's job, in effect, is to respond to the natural disturbances caused by non-human actors. Non-human actors are unable to speak for themselves and can only communicate this way. By bringing these concerns to the forefront of communication and media, it can only then become a public and social concern (Melián). "These different perspectives (or communication systems) complicate successful communication about ecological issues, since we have to consider that every observation has structural limits. Such complication also applies to any kind of scientific observation of nature. Hence the problem of social communication as such which is that of acquiring different kinds of insights" (Luhmann). "Scholars claim that a 'new vision' able to combine all of the different insights is required to change human behavior" (Graf 15). Through deliberative democracy this centralizes environmental concerns rather than downplaying them. Approaching this social structure empirically, a new style based on 
the common interest which addresses climate change could improve the relationship between society and the environment.

By providing a foundation that connects the community and the economy, there is opportunity for businesses, economists, policy makers, and people from the local to the national level to speak to the collaborative process. Changes can be made by widening the gap of communication and structuring a system of participation which allows for deliberation. The only way to achieve grand scale reduction on emissions is to open the conversation to those who contribute to the economy, which is every Canadian citizen.

The push for a grassroots deliberative process offers transparency of the township, city, state or country. By providing reliable information to citizens about the economy, future projects, and current situations, mini-publics create informed and just decisions. This process promotes interest in ongoing issues. Arguments aimed at the public good and generalized interest have the power to be more persuasive than those of self-interest. This is an important characteristic to acknowledge as this method has proven efficient to climate governance.

The radical transformation perspective is incompatible with the fact that environmental protection and economic growth can be achieved simultaneously. As suggested by Dryzek and Hajer's Cooperative Reformism, this concept considers both capitalism and sustainable goals (Bryer). The shift to a more sustainable system is a collaborative effort which requires governments, businesses, and civil society to envisage policies in order to put this into effect (Hajer). By acknowledging that everyone is responsible and has the ability to reduce fossil fuels, divestments can be made from fossil fuels and put into energy saving technologies. This ensures that environmental policies are protected. Implications of this shift consider inequalities from industrial and developing countries in order to move closer to a sustainable economy. The relationship between the communicative efforts behind economic development and environmental sustainability holds visions to an economy based on the pursuit of well-being and environmental quality (Dryzek, Politics).

\section{| Canada's Shortcomings on Environmental Management}

The Paris Agreement is the world's first comprehensive climate treaty. This agreement prides itself in its bottomup structure where the specific climate goals are politically encouraging rather than politically bound. Canada still falls short in many sectors as it works toward a clean and green economy. The organizing committee set a goal of limiting global warming to below $2.0-1.5{ }^{\circ} \mathrm{C}$. This goal requires a significant decrease in emissions between 2030 and 2050. The participating 196 countries agreed by consensus to this global pact. These commitments are ambitious and could also be a historical turning point although it is a non-binding contract. This agreement will not become binding until 55 parties which produce $55 \%$ of the world's greenhouse gases have ratified the agreement. Under this agreement, each country must regularly report on its contributions to mitigate global warming. One of the aims is also making finance flows consistent toward lowering greenhouse gas emissions. This principle of common respective capabilities between governments acknowledges each country's potential and duty to climate action. The Paris conference in 2015 reaffirmed the commitment for Canada to mobilize US $\$ 100$ billion a year in climate finance by 2025 ("Climate Change Canada"). Environmental liabilities are stated to be the most prominent global investment risk according to the World Economic Forum (WEF) on the 2020 report. Many government organizations around the world have invested in growing the fossil fuel divestment momentum. An example of this would be investors in 2019 which represent US\$11 trillion in assets from 1100 financial institutions committing to divest from fossil fuels. By working with national partners (Advisory Council on Climate Change, Low Carbon Economy Fund, and Climate Action Incentive) steps have been implemented by the green economy in order to create sustainable solutions.

In contrast, Canadian financial institutions and the federal and provincial government have not made any advances to adjust or implement changes on fossil fuel divestment. Currently, the UNFCCC states that Canada is working toward a transition to a low-carbon economy and renewable technology. In the Trudeau administration's 
second mandate there were two major initiatives regarding the petroleum sector. This would be one of the first actions with environmental initiatives made on the Trudeau administration's behalf. Although Canada's climate action plan provided by the UN is ambitious, the effort and actions are clearly contradictory. The vows for 2019-2020 include the construction of the Trans Mountain pipeline, and an offer by China for an offshore oil drilling project off the coast of Newfoundland. The recent assessment showed Newfoundland's offshore potential could exceed 50 billion barrels of oil and 200 trillion cubic feet of gas. "We expect to see at least eight wells drilled in the next year and a half, and as many as 100 over the next decade," Paul Barnes with the Canadian Association of Petroleum Producers says in an interview with the Chronicle Herald (Bundale). Despite opposition to take on these developments, Trudeau states: "We made a decision to move forward on the pipeline because it was in the interest of Canada to do so, because the environment and the economy need to go together. We will be continuing with the Trans Mountain pipeline expansion" ("Trudeau Extends Olive Branch"). The Trans Mountain pipeline expansion is designed to carry approximately a million barrels of oil from Alberta to the coast of British Columbia each day. The cabinet has acknowledged the potential of environmental and marine life damage. Trudeau states that the wealth created from this investment will be used into unspecified clean energy developments. The plan to invest profits from Trans Mountain has turned to an energy infrastructure project (Tasker). This claim made by Trudeau has been highly criticized by other parties as an effort to calm down the environmental and Indigenous groups who fiercely opposed the project. Among developed countries, Canada's support in transitioning to a cleaner future is weak.

The government has not committed to the Paris treaty, rather fueling the problem itself by giving over $\$ 1.3$ billion to the oil industry. Where the global public falls short in Canada's environmental management is the lack of transparency proceeding with the developments. Goals and aims of projects are never discussed to the extent to which the mini-publics can refute nor agree with enough substantial evidence. Information provided by the government is simply stated as future promises with no official planning put in place. Lack of pressure from the mini-publics is due to the ambiguity from the government. Examples of ambiguous claims made by Canada was Trudeau's statement after investing in the Trans Mountain National Pipeline. Not enough information or transparency has been shared in order for the public to form a just opinion or offer any solutions to the preceding.

The projected rate of growth from both the oil and tar sand industry prove that Canada's promises to take action on industrial pollution remain unregulated by the federal government. Some examples of this include the declining of clean energy investment in 2011 as Canada's federal government failed to renew and support renewable energy. Canada's federal government has also consistently declined support for climate change research as they are no longer funding the university-based climate research in Canada ("Climate Change Canada"). Canada is prioritizing their funds for institutional investors in order to maintain a high position on the global market. Though the economy is the foundation in the capital system, many other countries have made efforts to be sustainable.

Sweden has used political participation and is one of the strongest countries to cohere to the UN's sustainable goals. Co-managing strategies in Sweden which have incorporated deliberative elements have resolved natural resource issues and raised interest and awareness on key environmental problems. The approach includes interviews which covered personal roles, motives to participate, division of responsibilities, among many other methods to decision-making procedures. Results of this prove "deliberation is a way to produce the information required to take a collectively advantageous decision" (Zachrisson 278). By combining the scientific research of the government with ecological and practical knowledge of locals, the non-human actor can then be represented equally. Though it is important to recognize the federal government's role in climate governance, individuals and communities play an important role in the reduction of greenhouse gas emissions as well. By being as locally and ecologically aware of our towns or cities and our day-to-day actions we can be representative of the environment. 


\section{| The Future of Canadian Ecology Through Deliberative Processes}

Citizens must address the state of affairs in the system which is heavily reliant on capital. Using deliberative processes, current hedonistic systems also have the potential to change. One of the major contributors to greenhouse gas emissions is production. Transitions to artificial intelligence in the workplace and highly automated production lines do not support the green economy's goals; the sole interest lies in profit. Canada's reliance on input from shareholders, corporations, and investors has put pressure to make technological changes like this in order to cut labor costs without considering the sustainability of the environment, which will affect Canadian citizens. There is clear atypical construction in this transition, which is not beneficial to Canadians nor to the environment. By promoting a flexible system that supports small batch production, and higher levels of product differentiation, higher levels of skills for workers can also be achieved. This would also lessen the limited growth opportunity in workplaces. Michael Piore and Charles F. Sabel see potential that is contained with recent developments to manufacturing a sphere with flexible spatialization production. This approach offers a multiskilled workforce that owes their character to artisanal skills of old methods of craft by using small production and high levels of product differentiation that would push for controlled consumption. The second industrial divide that Piore and Sabel's theory outlines extends beyond just economic factors. This would result in new modes of regulation thus causing forms of industrial labor and social organization (Piore and Sabel).

Changing the labor production of Canada could be one of the most significant ways to reduce greenhouse gas emissions while also maintaining and even creating green jobs. Cap and trade systems and carbon taxes have not been effective enough on their own. Large corporations have only gotten better at finding loopholes. These practices should be penalized, and compliance measures in Canada right now are not being taken. As we have shifted into a throw-away society due to the effects of industrialization, there must be a push for a change in social structure that can only be implemented by the government. Green bonds were introduced this past decade in order to shift to cleaner technology. Broadly defined, green bonds are a fixed-income security project in order to raise capital for environmental benefits. Solutions such as green bonds and other compliance opportunities are not offered to mini-publics. Although the advantages of this investment are strong enough for individuals to benefit, this is only offered to stakeholders and institutions (Ontario Financing Authority). Stakeholders are large, profit-maximizing investors. The investments made by stakeholders place no pressure on enacting sustainable government policy. Increasing citizen stakeholders is more efficient in that both parties benefit while additionally providing the incentive to increase sustainability.

The current structure of this financial bond is a buyout which creates loopholes in order to continue unethical and unsustainable labor practices. These bonds that Canada offers, just as carbon tax, carbon transmission bonds, and cap and trade systems, are services that can be considered greenwashing. The government broadening the tax base is the primary objective in these investments. The secondary objective is to create minimal transparency with funds so as to avoid environmental responsibility. The compulsion to comply is not nearly strong enough for any of the investors to actually implement changes to current problems. They would rather give money to the government for future solutions to clean up their own transgressions.

The underlying issue with the Canadian government and their slow transition toward a green economy lies in the fact that it continues to neglect the power that its citizens can make in order to push for change. Investments, bonds, and taxes do not prove to be ethical or genuine in the engagement of green projects. Without corresponding direct beneficiaries, it is simple to make false claims. Stakeholders can blindly partake in these efforts offered legally by the government and feel ethically safe when the opposite of development is not offered by any government official or mandate to track these funds and keep progress of these projects. If individuals could issue green bonds in order to invest in Canada's transition to clean technology, this would be a much more effective push for change. A stronger sense of responsibility will be pushed on the government in order to actually construct and make changes rather than ensuring that it is one of the projects that will be 
considered. The reason it has not received enough pressure is because institutions have the funds to invest in order to feel ethically responsible while still being secure that they will be compensated in the end. These offers are loopholes of compliance measures. Stated under the Green Bond Principles is voluntary transparency. Issuers may seek external review in order to promote integrity but are not expected to provide full disclosure (Green Bond Principles).

The framework can very simply be reworked through communicative processes which openly discuss budgeting for future green projects, rather than leaving the mini-publics out of the opportunity to invest. Raddi Annab explains, "Corporations have been investing and issuing green bonds to be socially responsible, but also because they recognize that it's very appealing to the young generation and it drives customer loyalty because younger generations really care about climate change" (Saldanha).

The Bank of Canada has expressed climate change presenting risks to the financial sector. Subsidies of investors and the government are a clear indicator of where the priorities lie:

- Export Development Canada (EDC) invested 12 times more in oil and gas from 2012 to 2017.

- Within the first two years of the Trudeau administration, EDC spent \$22.4 billion on oil and gas investment, which is $\$ 2$ billion more than was spent on these sectors during the final two years of the Harper government.

- From 2013 to 2017, EDC invested \$4.4 billion in companies involved in oil sands expansion and transportation ("Climate Change Canada").

While many suggestions for local and government frameworks have been provided in order to transition to the green economy, Canada is in a fragile position amidst global competition. Solutions in order to achieve the green economy are outlined by the UNFCCC, but measures have yet to be implemented by the government. By keeping things institutional and private, it prevents citizens from taking steps toward a cleaner future as well.

\section{Conclusion}

Moving forward with social, political, and technological changes puts a strain on ethical and social responsibility on higher forms of government. Pushing for environmental responsiblility in order to pursue these projects as they were already disclosed with the public in Canada is only possible with engaged public awareness, consistent discourse, and deliberation. This ensures that plans concerning environmental and sustainable goals are met. The relationship of the public and private should be held at the forefront of the environmental movement in order for Canada to comply with the shift toward a green economy and clean future. Environmental sustainability can lead Canada to an economy which is based on the pursuit of well-being and environmental equality. It is Canada's duty to make sure that human and non-human actors are being considered in civil conversation with full disclosure of the preceding plans. Non-human actors like the environment have the ability to cause disruptions and disturbances that require immediate change to polity and social reformation. It goes without saying that this will also force complete transparency as shifts toward newer and sustainable energies, changed labor practices, and large investments need to be made in order to proceed with these actions accordingly. Concerning itself with mini and global publics is crucial to this transition. Deliberative polling processes should be implemented in order to discuss further solutions and have informational discussions with scientific research from the government of Canada, and ecological knowledge from citizens who will ultimately be directly affected by these transitions. 


\section{References}

Bryer, Thomas A. "Foundations and Frontiers of Deliberative Governance - by John S. Dryzek." Public Administration, vol. 91, no. 2, Blackwell Publishing Ltd, June 2013, pp. 508-10, doi:10.1111/j.1467-9299.2012.02103.x

Bundale, Brett. "Chinese Company Gets Green Light to Explore Offshore of Newfoundland and Labrador: The Chronicle Herald." Regional-Business | Business | The Chronicle Herald, 28 Dec. 2019, www.thechronicleherald.ca/business/regional-business/chinese-company-gets-green-light-to-explore-offshore-of-newfoundland-and-labrador-392428/?itm_source=parsely-api.

Bush, E. and Lemmen, D.S., editors. "Canada's Changing Climate Report," 2019. Government of Canada, Ottawa, ON. https://changingclimate.ca/CCCR2019/

"Changes in Temperature and Precipitation Across Canada." Chapter 4 - Canada's Changing Climate Report, changingclimate.ca/CCCR2019/chapter/4-0/.

"Climate Change Canada." Paris Agreement - Canada. ca, Government of Canada, 6 Jan. 2016, www.canada. ca/en/environment-climate-change/services/climate-change/paris-agreement.html.

Dewey, John. The Public and Its Problems. Athens, $\mathrm{OH}$ : Ohio University Press, 1954.

Dryzek, John S. Foundations and Frontiers of Deliberative Governance. : Oxford University Press, January 01, 2011. Oxford Scholarship Online. Accessed 29 Mar. 2020 <https://www.oxfordscholarship.com/ view/10.1093/acprof:oso/9780199562947.001.0001/ acprof-9780199562947>.

---. "Legitimacy and Economy in Deliberative Democracy." Political Theory, vol. 29, no. 5, 2001, pp. 651-669. JSTOR, www.jstor.org/stable/3072533. Accessed 30 Mar. 2020.

---. The Politics of the Earth: Environmental Discourses. 3rd ed., Oxford University Press, 2013.

Dryzek, J., Bowman, Q., Kuyper, J., Pickering, J., Sass, J., \& Stevenson, H. (2019). Deliberative Global Governance (Elements in Earth System
Governance). Cambridge: Cambridge University Press. doi:10.1017/9781108762922

Environmental Politics and Deliberative Democracy: Examining the Promise of New Modes of Governlance, edited by Karin Backstrand et al. Edward Elgar Publishing Limited, 2010. ProQuest Ebook Central, https://ebookcentral-proquest-com.libproxy.wlu.ca/lib/ oculwlu-ebooks/detail.action?doclD $=546594$

Falk, Johan, and Owen Gaffney. "Exponential Road Map Report.” Exponential Roadmap Initiative 1.5.1. 2020

Graf, Heike. The Environment in the Age of the Internet: Activists, Communication, and the Digital Landscape. OpenBook Publishers, 2016.

Green Bond Principles, www.icmagroup. org/green-social-and-sustainability-bonds/ green-bond-principles-gbp/.

Gutmann, Amy, and Dennis Thompson. Why Deliberative Democracy? Princeton, NJ: Princeton University Press, 2004.

Hajer, Maarten A. The Politics of Environmental Discourse: Ecological Modernization and the Policy Process. Clarendon, 1995.

Luhmann, Niklas. Ecological Communication. University of Chicago Press, 1989. MacDonald, DC. "Deliberative Polling as a Catalyst for Action on Climate Change." Center For Global Development, 21 Aug. 2014, https://www.cgdev.org/publication/ft/ deliberative-polling-catalyst-action-climate-change

Melián, Virginia. "The Environment in Disguise: Insurgency and Digital Media in the Southern Cone." The Environment in the Age of the Internet: Activists, Communication, and the Digital Landscape, edited by Heike Graf, 1st ed., Open Book Publishers, Cambridge, UK, 2016, pp. 21-52. JSTOR, www.jstor.org/stable/j.ctt1d41dkh.6. Accessed 3 Apr. 2020.

Ontario Financing Authority. https://www.ofina.on.ca/ greenbonds/ 2019. 
Piore, Michael J. and Charles F. Sabel. 1984. The Second Industrial Divide: Possibilities for Prosperity. New York: Basic Books. 1984

Raeijmaekers, Danielle, and Pieter Maeseele. "Media, Pluralism and Democracy: What's in a Name?" Media, Culture \& Society, vol. 37, no. 7, Oct. 2015, pp. 10421059, doi:10.1177/0163443715591670.

Saldanha, Ruth. "Are 'Green Bonds' Green?” Morningstar CA, Morningstar, Inc., 27 Sept. 2019, www.morningstar. ca/ca/news/195853/are-'green-bonds-green.aspx.

"Shareable Infographics." Global Risks Report 2020, reports.weforum.org/global-risks-report-2020/ shareable-infographics/.

Stevenson, Hayley. "Contemporary Discourses of Green Political Economy: A Q Method Analysis." Journal of Environmental Policy \& Planning, vol. 21, no. 5, 2019, pp. 533-548. doi: $\underline{10.1080 / 1523908 X .2015 .1118681}$

"Trudeau's Claim That Canada Is 'on Track' to Meet 2030 Climate Target Is Misleading | CBC News." CBCnews, CBC/Radio Canada, 25 Sept. 2019, www.cbc.ca/news/politics/ trudeau-climate-change-2030-fact-check-1.5295961.

"Trudeau Extends Olive Branch to Western Canada, Vows to Build Trans Mountain despite Opposition | CBC News." CBCnews, CBC/Radio Canada, 23 Oct. 2019, www.cbc.ca/news/politics/ trudeau-western-canada-trans-mountain-1.5332365.

UN. "Green Economy." UNEP - UN Environment Programme, https://www.unenvironment.org/ regions/asia-and-pacific/regional-initiatives/ supporting-resource-efficiency/green-economy

Zachrisson, Anna. "Deliberative Democracy and CoManagement of Natural Resources: Snowmobile Regulation in Western Sweden." International Journal of the Commons, vol. 4, no. 1, 2010, pp. 273-292. JSTOR, www.jstor.org/stable/26523023. Accessed 4 May 2020. 